\title{
Nonylphenol: Properties, legislation, toxicity and determination
}

\author{
FREDERICO G. DE ARAUJO ${ }^{1}$, GLAUCO F. BAUERFELDT ${ }^{1}$ and YARA PELUSO CID ${ }^{2}$ \\ ${ }^{1}$ Chemistry Department, Rural Federal University of Rio de Janeiro, BR 465, Km 47, 23890-000 Seropédica, RJ, Brazil \\ ${ }^{2}$ Phamaceutical Science Department, Rural Federal University of Rio de \\ Janeiro, BR 465, Km 47, 23890-000 Seropédica, RJ, Brazil
}

Manuscript received on March 3, 2017; accepted for publication on May 23, 2017

\begin{abstract}
This paper aims to gather and discuss important information about nonylphenol, such as physical chemistry properties, toxicity and analytical methods in various matrices. As a degradation product of ethoxylated alkylphenols, nonylphenol presents a higher degree of reactivity than its precursor. Due to its harmful effects on the environment, use and production of nonylphenol has been banned in European Union countries, alongside their precursors. The guide on quality of drinking water (USEPA) recommends a maximum concentration of $28 \mu \mathrm{g} \mathrm{L}^{-1}$ for fresh water. In Brazil, there is no clear legislation containing values of maximum concentration of nonylphenol. Due to this lack of regulation, a continuous monitoring is necessary of this pollutant in environmental samples. This paper aims to encourage further studies on nonylphenol, seen as a critical environmental pollutant. For proper monitoring is necessary to have reliable analytical methods and easy to perform in routine analysis.
\end{abstract}

Key words: nonylphenol, endocrine disrupter, pollutant, water analysis.

\section{INTRODUCTION}

Nowadays, the growing concern over water resources availability is justified by its key role in the socioeconomic development of humanity. Availability which is affected not only by water scarcity in some regions, or the increase in world demand, but also by the depreciation of its quality. Considering the uncontrolled growth of cities and human activities in the surrounding watershed, it is worth noticing the increased pollution of surface

Correspondence to: Yara Peluso Cid

E-mail: yarapcid@gmail.com

* Contribution to the centenary of the Brazilian Academy of Sciences. and groundwater (Rebouças 2001, Vianna 2015, Tundisi 2008). In Brazil, even with investments in sewage systems and treatment plants, only a small portion of the sewage volume generated by cities is effectively treated before reaching the rivers. The release of sewage into water bodies without any treatment is one of the main causes for depreciation of water quality. The absence of adequate basic sanitation compromises the primal use of this resource, the public supply. Such context imposes a continuous need for finding even further sources, more complex and more expensive chemical treatments to ensure availability of drinking water (Tucci 2008). 
A general concern has been raising worldwide about the contamination of the environment (air, soil, forests, animals, rivers and oceans by chemicals from industrial activities, mineral exploration and agricultural exploitation) and its relation to the recent increase of congenital malformations, asthma, cancer and neurological and behavioral disorders in children (Godoi et al. 2003, Mello-daSilva and Fruchtengarten 2005).

The concern about the contamination of surface and underground water systems with pesticides has grown in the world. In industrialized countries, the Green Revolution of the 1960s significantly increased agricultural productivity due to the expansion of sown area, mechanization, pest control, among others. For pest control, the massive use of pesticides was necessary, dangerous chemicals used to repel or kill rodents, fungi or insects potentially harmful to intensive agriculture. These extensively used chemicals, at first sight, bring a great benefit to human health, by increasing agricultural productivity. On the other hand, many of those first-generation pesticides are harmful to the environment. Some of them can persist in soils and aquatic sediments, bioaccumulate in the tissues of invertebrates and vertebrates, moving in trophic chains, and affect top predators (Mnif et al. 2011).

After the Second World War the sale and trading of chemicals, such as fertilizers, pesticides and insecticides increased sharply. This increase was justified by industrial development and the need to supply the demand of the population for food and to improve the quality of crops (Colborn et al. 1994, El-Shahawi et al. 2010). Meanwhile, the problem of environmental pollution has emerged, particularly regarding water, soil and air The organic compounds released into the environment, or formed from the degradation of other compounds, generally present a high toxicity that may chronically alter the development and reproduction of aquatic life (Ghiselli and Jardim 2007).
Water resources pose as the final destination of the main pesticides, considering surface and underground resources. Soil and water operate interactively and any action that causes adverse effect in one of these will affect the other. In some cases, less than $0.1 \%$ of the amount of applied pesticides reaches the target species while the remaining $(99.9 \%)$ has the potential to move to other environmental compartments, such as surface water and groundwater through natural processes as leaching, volatilization, degradation, sorption and plant uptake (Ribeiro et al. 2007).

The formulation of the pesticide contains components such as adjuvants and usage modifiers, in addition to the active ingredient. Amongst the adjuvants, there are the surfactants, stickersspreaders, wetting agents, to name but a few. Regarding utility modifiers, there are buffering agents to alter and stabilize solution's $\mathrm{pH}$ and enhance active ingredient solubility; and there are also compatibility agents, to mitigate compatibility problems arising from the mix of multiple pesticides, or pesticides and fertilizers (Fraga 2012).

Surfactants are compounds able to change the surface and interfacial properties of a liquid mixture. They form aggregates, called micelles, usually in low concentrations in solution, decreasing the surface tension of the system and contributing to the stability of the mixture. These compounds are classified into four types, which takes into account the nature of the hydrophilic group: non-ionic, anionic, cationic and amphoteric (Fernandes Providello et al. 2006). After use, residual surfactants are directly released into the sewage system or directly to surface waters, causing pollution of the aquatic system and forming degradation products (Aloui et al. 2009).

The alkylphenol ethoxylate (APEO), nonionic surfactants has been widely used in phenolic resins, plastics additives, detergents, emulsifiers, pesticides formulations among others. The most relevant APEO is nonylphenol ethoxylate 
(NPnEO), representing approximately $80 \%$ of production, of which $60 \%$ has the environment as a final destination (Renner 1997, Solé et al. 2000, Zgola- Grześkowiak et al. 2009).

Nonylphenol is formed during anaerobic breakdown of the ethoxylated alkylphenols (APEO). In the absence of oxygen, nonylphenol formation is favored (4 to 8 times) when compared to aerobic. Under aerobic conditions, the APEO degrade through either the loss of ethylene oxide units to form low-molecular weight ethoxylates or through the formation of carboxylated ethoxylates ultimately terminating in $\mathrm{CO}_{2}$ and water. Studies have demonstrated that derivatives of ethoxylated alkylphenols are more persistent and toxic than the parent substances also having the ability to cause disruption of natural hormones to interact with the estrogen's receptor (Renner 1997). It has also been demonstrated (Ahel et al. 1994) that nonylphenol can be degraded by photochemical processes. In bright summer sun, nonylphenol near the water surface has a half-life of 10-15 hr. Another study by Ahel et al. (1996) demonstrated that nonylphenol can be reduced in ground water. The authors suggest that biological processes are responsible provided that the ground water temperature does not become too cold for biological degradation. The authors suggested that this reduction involves biological processes occurring in the part nearest to the river aquifer, provided the groundwater temperature is not low enough for biological degradation (Solé et al. 2000, Zgola- Grześkowiak et al. 2009, Ahel et al. 1994, 1996).

Due to the rapid biodegradation of the alkylphenol ethoxylate, generating more toxic metabolites with potential endocrine disruption, the European Commission, through Directive $n^{\circ}$ 2003/53/EC banned their use in the European Union. However, the control of the application of these compounds in agriculture is not easy, since many of the products commercially available carry in restricted or no label information about the presence of surfactants in their formulation (ZgolaGrześkowiak et al. 2009).

\section{NATIONAL AND INTERNATIONAL LEGISLATION} ON ENDOCRINE DISRUPTERS IN WATER

Over the past few years, a great number of studies trend a growing concern about exposure to chemicals that can interact with the endocrine system and cause adverse effects on wildlife and humans. Studies indicate the presence of these chemicals, called endocrine disruptors in wastewater treatment plants, surface water and groundwater due to the low efficiency of the water treatment process. That is, even after conventional treatment, the water body receptor may still be contaminated (Meyer et al. 1999, Bila et al. 2007). The shortage of water resources is an issue faced by many countries, including Brazil. Highlighting the increasingly imperative need for new studies on the impacts of these disruptors in all beings included in this scenario, studies on water quality among others.

Table I shows the maximum allowed values of some EDs according to the regulation currently enforced both in Brazil and the United States, for surface water and supply as well as the guidance value provided by the Drinking Water Quality Guide World Health Organization Health. Some compounds recently characterized as endocrine disruptors, such as bisphenol a, are not included in the regulations presented in this table.

The guidelines on the quality of US water consumption is given by the Safe Drinking Water Act, establishing the maximum level of contaminants that may be acceptable in drinking water, and the goal of the maximum level of contaminants. Although not enforced as a law, the guide regulates the concentration below which risks to human health are not presented. In addition, another guide is the National Recommendation of Water Quality Criteria (USEPA 2015). 
TABLE I

Maximum concentration ( $\left.\mu \mathrm{g} \mathrm{L}^{-1}\right)$ of endocrine disruptors in drinking water (1) and surface water (2) in accordance with national and international laws.

\begin{tabular}{|c|c|c|c|c|c|}
\hline \multicolumn{6}{|c|}{ Maximum concentration $\left(\mu g \mathrm{~L}^{-1}\right)$} \\
\hline \multirow[b]{2}{*}{ Composto } & \multicolumn{2}{|c|}{ Brazil } & \multicolumn{2}{|c|}{ USA } & \multirow{2}{*}{$\begin{array}{c}\text { WHO } \\
1^{\mathrm{e}}\end{array}$} \\
\hline & $1^{\mathrm{a}}$ & $2^{b}$ & $1^{\mathrm{c}}$ & $2^{d}$ & \\
\hline Benzopyreno & 0.7 & $0.018^{\mathrm{c}}$ & 0.2 & n.m..$^{f}$ & 0.7 \\
\hline Nonylphenol & n.m. & n.m. & n.m. & $28^{\mathrm{g}} / 7^{\mathrm{h}}$ & n.m. \\
\hline Pentachlorophenol & 9 & 3 & 1 & $19^{\mathrm{g}} / 13^{\mathrm{h}}$ & 9 \\
\hline Dihexyl-phthalate & 20 & n.m & 6 & n.m. & 8 \\
\hline
\end{tabular}

a: Portaria MS 2914/2011 (BRASIL 2011); b: Resolução CONAMA 357/2005 (BRASIL 2005); c: Safe Drinking Water Act, SDWA(USEPA 2004); d: National recommendation of water quality criteria (USEPA 2009); e: World Health Organization; f: not mentioned value; g: fresh water; h: salty water.

Brazilian regulation is cosisted of basically two guides: Resolution 357/2005 from CONAMA (National Environmental Agency) (Brasil 2005), for water bodies contamination assessment; and Resolution 2914 from the National Ministry of Health, to stablish and ensure drinkability in public suply.

\section{PHYSICOCHEMICAL PROPERTIES OF NONYLPHENOL}

Nonylphenol has a molecular formula $\mathrm{C}_{15} \mathrm{H}_{24} \mathrm{O}$ $\left(\mathrm{M} . \mathrm{M}=220 \mathrm{~g} \mathrm{~mol}^{-1}\right)$. In environmental conditions, it is a viscous liquid, slightly soluble in water (4.90 $\mathrm{mg} \mathrm{L}^{-1}$ at $25^{\circ} \mathrm{C}$ ) and soluble in common organic solvents such as acetonitrile and methanol. It has melting point of $-10{ }^{\circ} \mathrm{C}$, boiling point of $304{ }^{\circ} \mathrm{C}$, density of $0.6 \mathrm{~g} \mathrm{~mL}^{-1}$ at $20^{\circ} \mathrm{C}$, the vapor pressure of $1.33 \mathrm{~Pa}\left(20^{\circ} \mathrm{C}\right)$ and $\log \mathrm{P}$ in the range of 4.36 to 4.60. In aqueous solution, it behaves as a weak acid with $\mathrm{pKa}=10,7$.

\section{TOXICITY}

After establishing that nonylphenol brings risk to people, the use of its precursor was banned in many countries and replaced by other surfactants, providing more safety for the population and the environment (Soares et al. 2008).
The US Environmental Protection Agency defines an endocrine disrupter compound as "an exogenous agent that interferes with the synthesis, secretion, transport, metabolism, binding or elimination of the body's natural hormones, which are responsible for homeostasis, reproduction, development and / or behavior" (USEPA 1998).

To assess the toxicity of environmental contaminants in aquatic organisms, ecotoxicity tests using algae, bacteria, aquatic invertebrates, zooplankton and fish as test organisms are available. In these tests, not only parameters of toxicity are evaluated, but also biochemical, physiological and behavioral parameters. The acute toxicity of nonylphenol for freshwater animals can vary from $20.7 \mu \mathrm{g} \mathrm{L}^{-1}$ for the amphipod Hyalella azteca to $774 \mu \mathrm{g} \mathrm{L}^{-1}$ for snail Physella virgate. At last, chronic toxicity of nonylphenol for freshwater animals ranges from $10.18 \mu \mathrm{g} \mathrm{L}^{-1}$ for the fish species Pimephales promelas to $157.9 \mu \mathrm{g} \mathrm{L}^{-1}$ for the crustacean Daphnia magna (USEPA 2005). Azevedo et al. (2001), mentions that the range of concentrations commonly found in rivers is between 0.2 e $12 \mu \mathrm{g} \mathrm{L}^{-1}$, values that are already likely to cause problems for some organizations (Azevedo et al. 2001). 


\section{SAMPLE PREPARATION}

For the determination of analytes in environmental matrices becomes generally required isolation, preconcentration and possibly a cleaning step (cleanup) due to the complexity of the matrix. Among the applied extraction methods for the determination of nonylphenol in water are liquid-liquid extraction (LLE), the solid phase extraction (SPE) solidphase micro extraction (SPME) and dispersive liquid-liquid micro extraction (DLLME). In solid matrices or sewage sludge extractors type soxhlet and extraction assisted by ultrasound, extraction accelerated solvent (ASE) and pressurized liquid extraction (PLE) are most widely used. Table II presents an overview of nonylphenol extraction methods, liquid and solid matrices described more recently.

The efficiency of the extraction process is directly related to the $\mathrm{pH}$ of the matrix where nonylphenol is found. The interference of the liquid matrix $\mathrm{pH}$ is given by the fact that nonylphenol may have a nonpolar character in the $\mathrm{pH}$ range from 0 to approximately 10 and a polar character in $\mathrm{pH}$ above 10.7. Consequentially, nonylphenol has greater solubility in the matrix with more alkaline character, because in this $\mathrm{pH}$ condition, nonylphenol presents greater ionic character, thereby increasing its water affinity.

For liquid samples the predominantly used method was SPE. The most commonly used solid phase was the nonpolar character (C18) (Liu et al. 2004, Cai et al. 2003, Ciofi et al. 2014, Souza, 2011 Fabregat-Cabello et al. 2013, Petrie et al. 2013, Martinez and Peñuela 2013, de Sousa Leite et al. 2010, Gatidou et al. 2007, Petrovic et al. 2003, Jeannot et al. 2002, Díaz et al. 2002, Fiedler et al. 2007, Su et al. 2012), but also observed in works which deployed solid phase of polymeric nature, with retention capability of polar and nonpolar analytes together (Azevedo et al. 2001, Jeannot et al. 2002, Terzopoulou et al. 2014, Kuch and
Ballschmiter 2001, Montagner and Jardim 2011, Sodré et al. 2010b, Huerta et al. 2015, Cruceru et al. 2012). The major part of SPE uses cartridges containing $500 \mathrm{mg}$ of solid phase and $6 \mathrm{ml}$ volume capacity, but there are also works describing cartridges used with different stationary phase masses, such as $1000 \mathrm{mg}, 60 \mathrm{mg}$ and $200 \mathrm{mg}$. Other techniques used for extraction of nonylphenol in liquid samples are liquid-liquid extraction (Cruceru et al. 2012, Oketola and Fagbemigun 2013), the addition of ultrasound with SPE (Huerta et al. 2015), use of DLLME (Sun et al. 2013), and use of SPME (Díaz et al. 2002, Hernández et al. 2007).

In some protocols shown in Table II, there is the inclusion of yet another step, cleaning (cleanup). This step has the purpose of removing any interferences that may have been trapped on the solid phase cartridge and cause problems to the other stages. For this step, it is necessary to select a solvent in which such interferences are soluble (to promote desorption of the solid phase), although the washing solvent must not desorb the analyte. In the analyte desorption step, a great variety of solvents are used, such as methanol (Ciofi et al. 2014, Fabregat-Cabello et al. 2013, Petrovic et al. 2003, Fiedler et al. 2007, Montagner and Jardim 2011, Sodré et al. 2010a), ethyl acetate (Liu et al. 2004), dichloromethane (Martinez and Peñuela 2013), mixture of methanol and water (Cai et al. 2003), acetonitrile and dichloromethane (Azevedo et al. 2001), ethyl acetate and methanol (Souza 2011), dichloromethane and methanol (de Souza Leite et al. 2010, Su et al. 2012), dichloromethane e hexane (Gatidou et al. 2007, Terzopoulou et al. 2014), acidified methanol and dichloromethane (Díaz et al. 2002), methanol and ethyl ether (Jeannot et al. 2002), acetone and methanol (Kuch and Ballschmiter 2001, Sodré et al. 2010b) and methanol, acetic acid and acetone mixture with dichloromethane (Petrie et al. 2013).

The extraction procedure for solid phase involves two steps: one sorption stage where 


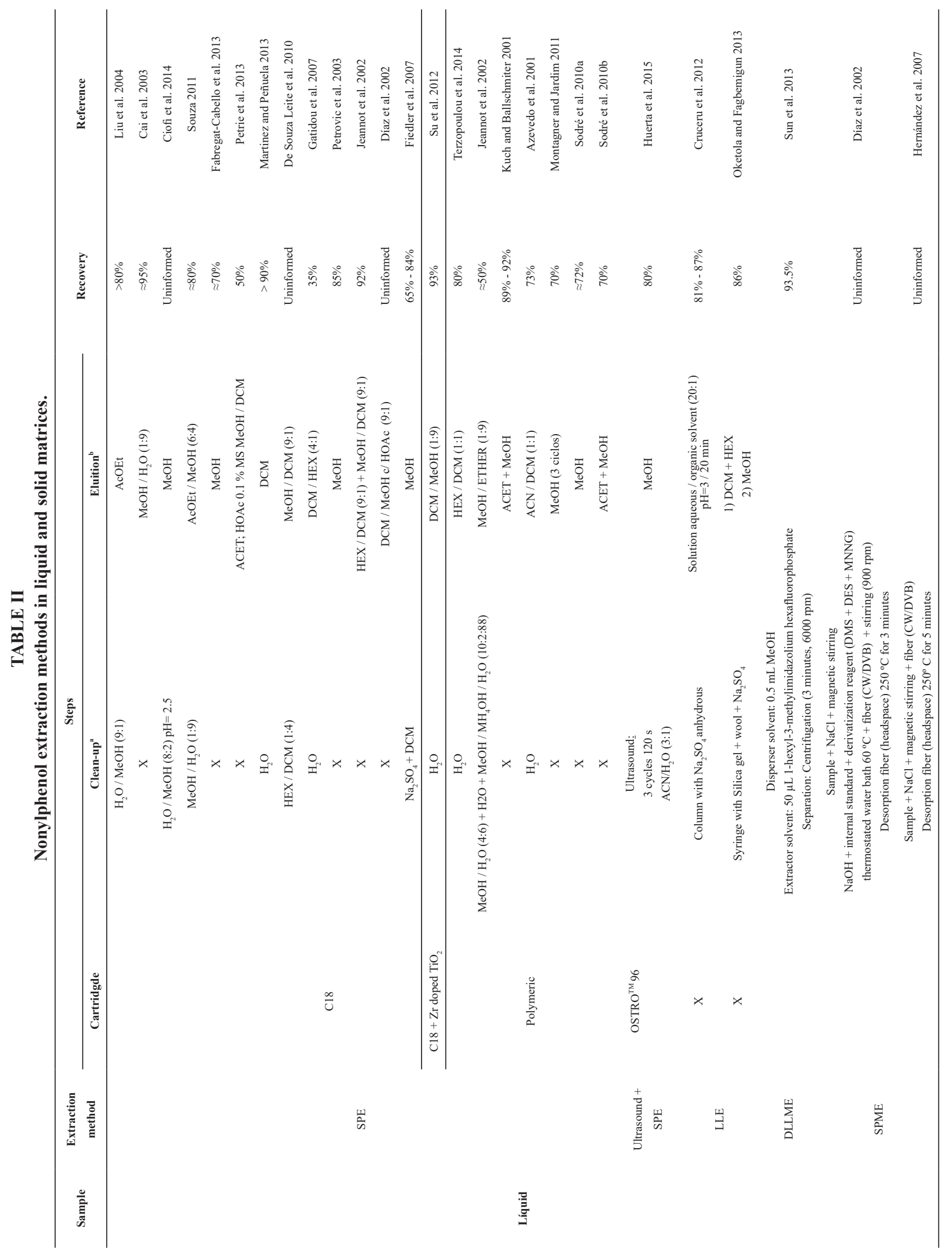




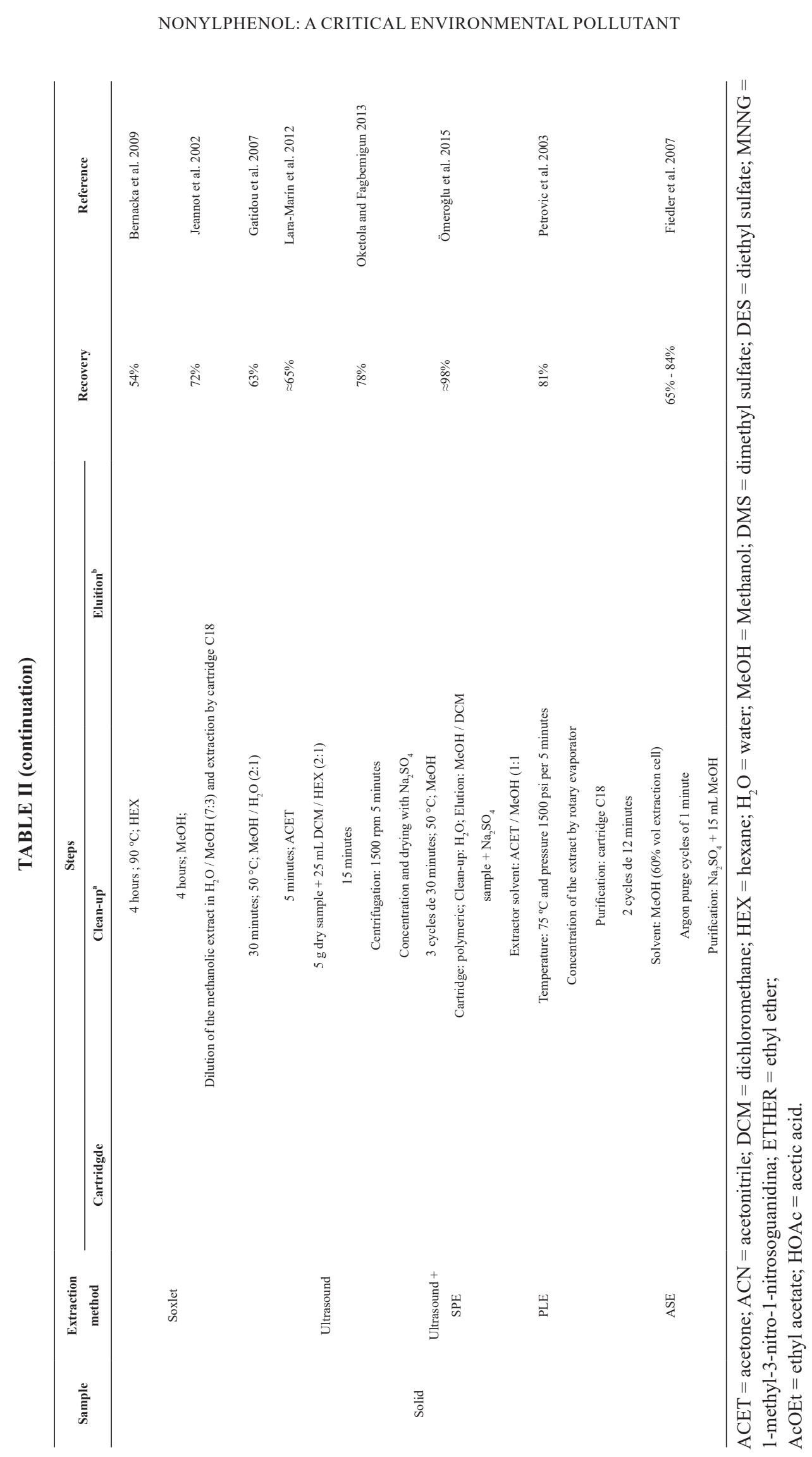

An Acad Bras Cienc (2018) 90 (2 Suppl. 1) 
a solid phase presents similar character with the analyte, thereby increasing the value of the partition coefficient. The other step involves the desorption of the analyte, which requires a solvent having high affinity with the analyte to promote the desorption of the solid phase, so that the partition coefficient is the lowest possible. The selection of solid phase and eluting solvent influences considerably the analyte recovery results, as shown in Table I. For nonylphenol, most studies use solid phase hydrophobic character (C18), as the solid phase has a similar character to the analyte (nonpolar), increasing the sorption in phase and causing increased coefficient of analyte solid-phase partition. Regarding elution solvent, it must present characteristics similar to the analyte, thus providing sufficient strength to promote the desorption of the analyte from the solid phase. As a consequence of these two factors, an erroneous choice of solid phase and / or the eluting solvent will cause the extraction procedure to present low recovery values.

Regarding solid matrices, there is a scarce number of works to be found, and the predominantly used method of extraction was the ultrasound (Gatidou et al. 2007, Oketola and Fagbemigun 2013, Lara-Martin et al. 2012). It is also observed the use of soxhlet (Jeannot et al. 2002, Bernacka et al. 2009), ultrasound and SPE (Ömeroğlu et al. 2015), PLE (Petrovic et al. 2003) e ASE (Fiedler et al. 2007). In these extraction methods for solid matrices, it is also observed the use of large amounts of sample, reaching $500 \mathrm{~g}$ of sample, and exceedingly lengthy protocols. The use of methanol or acetone in the procedures with ultrasound and the use of the extraction using hexane due to the structural similarity with the analyte can also be observed.

ANALYTICAL METHODS FOR THE QUANTIFICATION OF NONYLPHENOL

Given the low polarity of nonylphenol molecule, methods of analysis based on high-performance liquid chromatography (HPLC) and gas chromatography (GC) have been developed. Due to this fact, most investigations reported in the literature refers to these analytical techniques. For most cases, independent of matrix, the use of mass spectrometry (MS) for the detection of nonylphenol is observed, but also observed is the usage of other detectors such as molecular absorption spectrophotometry in ultra-violet (UV) and fluorescence (FLU).

The chromatographic analytical methods for determination of nonylphenol in liquid and solid matrices are shown in Tables III and IV respectively.

For liquid samples, there is use of GC-MS (Azevedo et al. 2001, Liu et al. 2004, Martinez and Peñuela 2013, Jeannot et al. 2002, Terzopouliu et al. 2014, Kuch and Ballschmiter 2001, Sodré et al. 2010b, Oketola and Fagbemigun 2013, Díaz et al. 2002, Hernández et al. 2007, Planas et al. 2002), HPLC-FLU (Zgola-Grześkowiak et al. 2009, Cai et al. 2003, Lou et al. 2012, Marcomini and Giger 1987, Ahel et al. 2000), HPLC-UV (Montagner and Jardim 2011, Marcomini and Giger 1987, Fytianos et al. 1997, Cao et al. 2013) and HPLC-MS (Ciofi et al. 2014, Petrovic et al. 2003, Jeannot et al. 2002, Sodré et al. 2010a, Sun et al. 2013). Among the methodologies using HPLC, most make use of a reverse phase column, including columns with eighteen carbon bonded silica (C18) (ZgolaGrześkowiak et al. 2009, Petrovic et al. 2003, Jeannot et al. 2002, Montagner and Jardim 2011, Sodré et al. 2010a, Sun et al. 2013, Lou et al. 2012, Fytianos et al. 1997, Cao et al. 2013), columns with 8 carbons attached to silica (C8) (Cai et al. 2003, Marcomini and Giger 1987, Ahel et al. 2000) and columns with pentafluorophenyl as stationary phase (Ciofi et al. 2014).

Regarding the detection limit and quantification values found by the authors, there is value in the concentration range of $\mathrm{ng} \mathrm{mL}^{-1}$ (Cai et al. 2003), ng L ${ }^{-1}$ (Liu et al. 2004, Martinez and Peñuela 2013, Petrovic et al. 2003, Jeannot et al. 2002, 


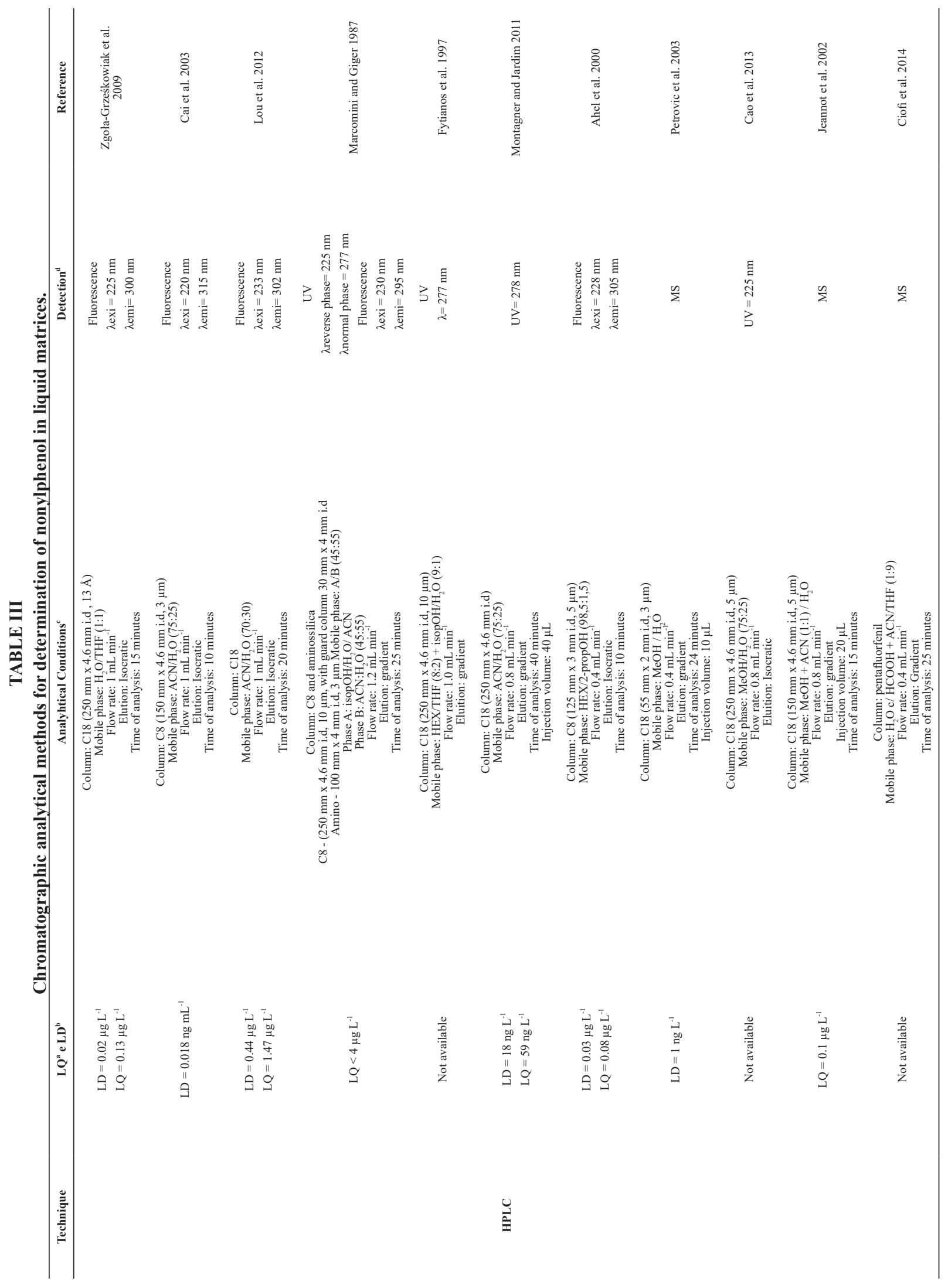




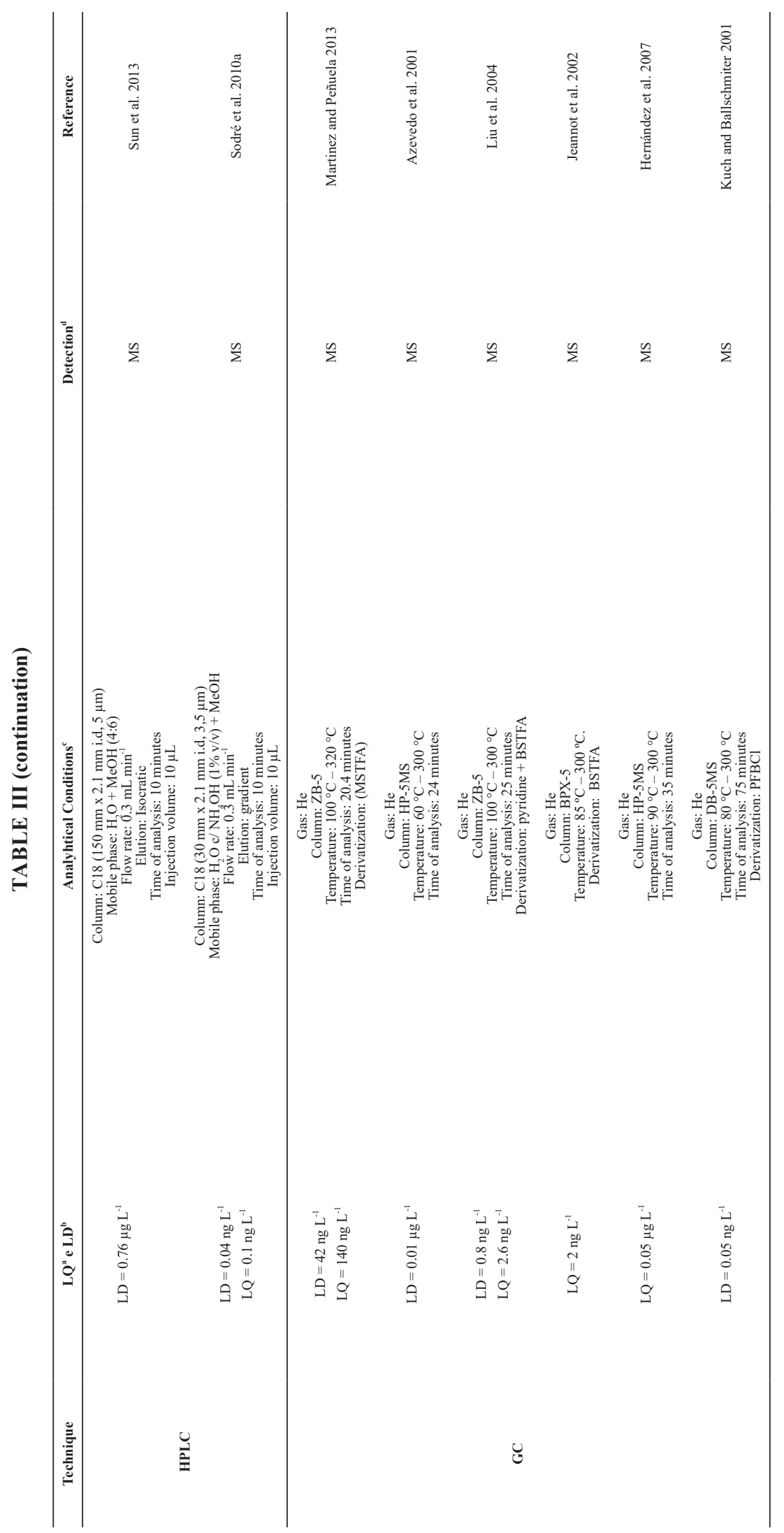


NONYLPHENOL: A CRITICAL ENVIRONMENTAL POLLUTANT

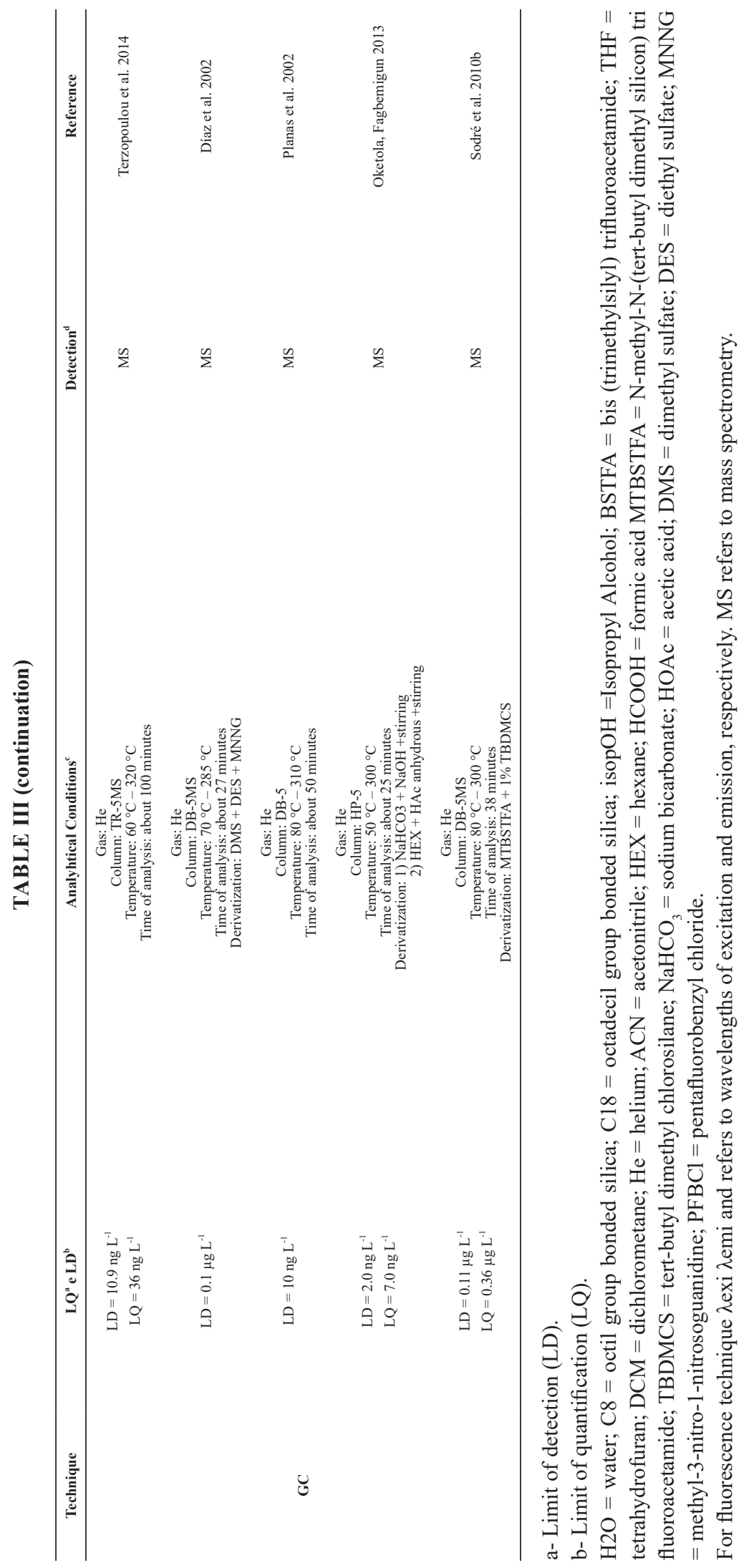




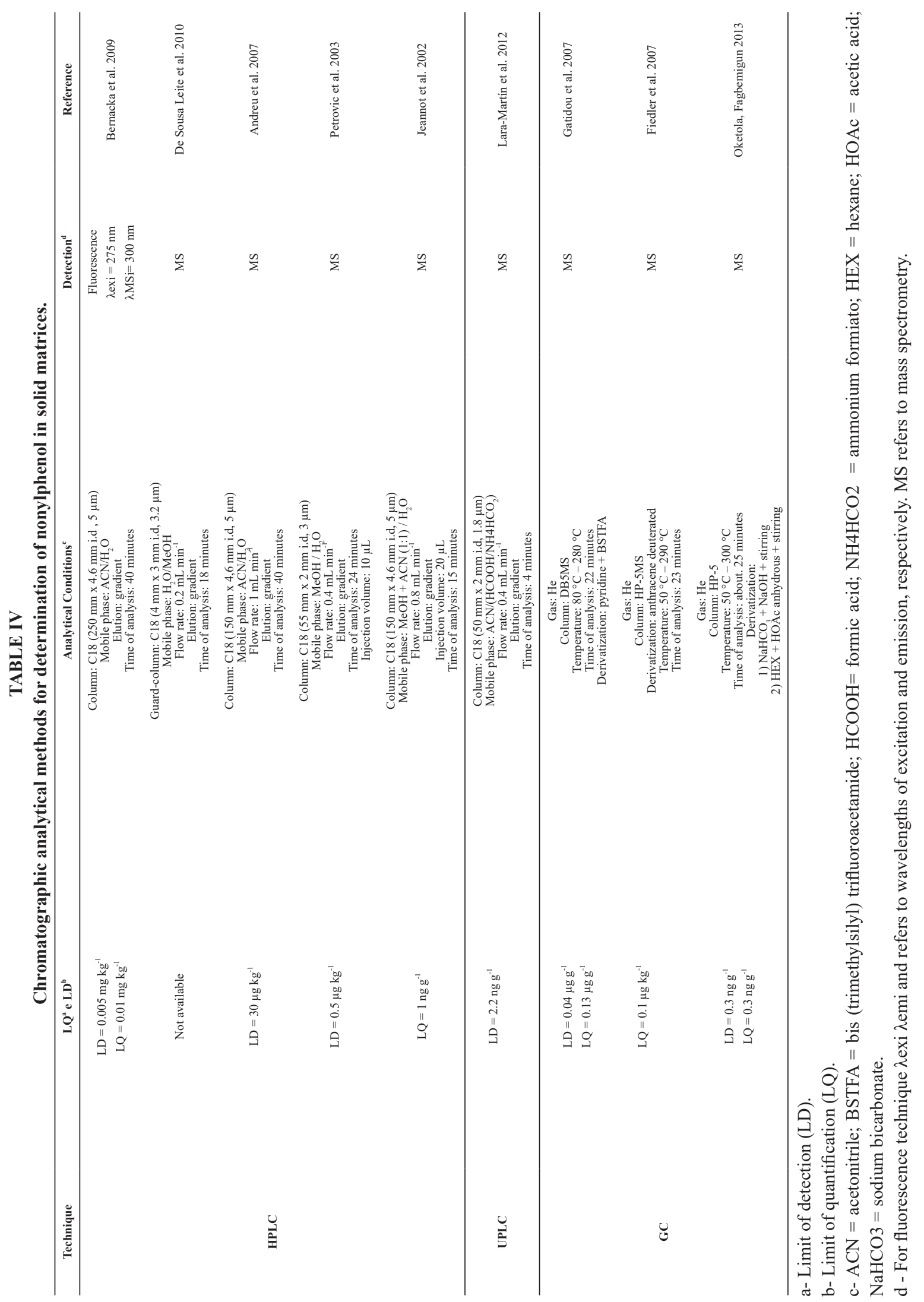


Terzopoulou et al. 2014, Kuch and Ballschmiter 2001, Montagner and Jardim 2011, Sodré et al. 2010a, Oketola and Fagbemigun 2013, Planas et al. 2002) and also in the concentration range $\mu \mathrm{g}$ $\mathrm{L}^{-1}$ (Zgola-Grześkowiak et al. 2009, Azevedo et al. 2001, Jeannot et al. 2002, Sodré et al. 2010b, Sun et al. 2013, Díaz et al. 2002, Hernández et al. 2007, Lou et al. 2012, Marcomini and Giger 1987, Ahel et al. 2000).

For solid samples, it can be observed using HPLC-FLU (Bernacka et al. 2009), GC-MS (Gatidou et al. 2007, Fiedler et al. 2007, Oketola and Fagbemigun 2013), HPLC-MS (de Souza Leite et al. 2010, Petrovic et al. 2003, Andreu et al. 2007) and UPLC-MS (Lara-Martin et al. 2012). The detection and quantification limit values have a concentration range from $\mathrm{ng} \mathrm{g}^{-1}$ (Jeannot et al. 2002, Oketola and Fagbemigun 2013, Lara-Martin et al. 2012), $\mu \mathrm{g} \mathrm{g}^{-1}$ (Gatidou et al. 2007), $\mu \mathrm{g} \mathrm{kg}^{-1}$ (Petrovic et al. 2003, Fiedler et al. 2007, Andreu et al. 2007) to $\mathrm{mg} \mathrm{kg}^{-1}$ (Bernacka et al. 2009).

As it may be observed in the tables above, the type of matrix and machinery, together with the type of detector, provide a detection limit of quantification and lower values than others. It can be observed in tables III and IV how these factors can greatly interfere with the detection and quantification limit values, causing works that use the same hyphenated techniques to find distinct detection and quantification limit values. Tables 3 and 4, show that in the vast majority of studies published detection limit values and quantification below the maximum level of contaminants recommended by the USEPA as shown in Table I. Thus, demonstrating that the methods already developed and validated by the authors, have great use in environmental monitoring of nonylphenol in liquid and solid matrices. Tables III and IV list the following works which were carried out in Brazil (Azevedo et al. 2001, de Souza Leite et al. 2010, Fiedler et al. 2007, Montagner and Jardim 2011, Sodré et al. 2010a, b). These studies were carried out both in liquid and solid matrices and set quantification limits for liquid samples in the range of $n g \mathrm{~L}^{-1}$ to $\mu \mathrm{g} \mathrm{L}^{-1}$. As for solid samples, the limit of quantification reported by the brazilian authors were in the range of concentration $\mathrm{mg} \mathrm{kg}^{-1}$.

\section{CONCLUSIONS}

Nonylphenol has endocrine disrupting capacity and is characteristically prone to accumulating on the environment with high organic matter content. It has low solubility in water, which can cause difficulty in their monitoring in environmental samples. Although there is a significant amount of studies involving determination of nonylphenol in environmental samples, there are few studies in Brazil. The lack of national publications combined with lack of legislation setting nonylphenol limits in Brazil underscores the need to develop analytical methods with analytical reliability for determination of this analyte, and the implementation of monitoring programs to better assess the quality of the environment.

\section{ACKNOWLEDGMENTS}

The autors thank the Conselho de Aperfeiçoamento de Pessoal de Ensino Superior (CAPES) and Comitê das bacias hidrográficas dos rios Guandu, da Guarda e Guandu-Mirim for financial support.

\section{REFERENCES}

AHEL M, GIGER W, MOLNAR E AND IBRIC S. 2000. Determination of nonylphenol polyethoxylates and their lipophilic metabolites in sewage effluents by normal-phase high-performance liquid chromatography and fluorescence detection. Croat Chem Acta 73: 209-227.

AHEL M, SCHAFFNER C AND GIGER W. 1996. Behaviour of alkylphenol polyethoxylate surfactants in the aquatic environment-III. Occurrence and elimination of their persistent metabolites during infiltration of river water to groundwater. Water Res 30: 37-46.

AHEL M, SCULLY FE, HOIGNÉ J AND GIGER W. 1994. Photochemical degradation of nonylphenol 
and nonylphenol polyethoxylates in natural waters. Chemosphere 28: 1361-1368.

ALOUI F, KCHAOU S AND SAYADI S. 2009. Physicochemical treatments of anionic surfactants wastewater: Effect on aerobic biodegradability. J Hazard Mater 164: 353-359.

ANDREU V, FERRER E, RUBIO JL, FONT G AND PICÓ Y. 2007. Quantitative determination of octylphenol, nonylphenol, alkylphenol ethoxylates and alcohol ethoxylates by pressurized liquid extraction and liquid chromatography-mass spectrometry in soils treated with sewage sludges. Sci Total Environ 378: 124-129.

AZEVEDO DDA, LACORTE S, VIANA P AND BARCELÓ D. 2001. Occurrence of Nonylphenol and Bisphenol-A in Surface Waters from Portugal. J Braz Chem Soc 12: 532-537.

BERNACKA J, CHABER P, KONDZIELSKI I AND POLUBIEC E. 2009. 4-Nonylphenols and Their Ethoxylates in Sewage Sludge From Polish Municipal Wastewater. Environ Prot Eng 35: 65-79.

BILA D, MONTALVÃO AF, AZEVEDO DA AND DEZOTTI M. 2007. Estrogenic activity removal of $17 \beta$-estradiol by ozonation and identification of by-products. Chemosphere 69: 736-746.

BRASIL. 2005. Conama Resolução n 357, Diário Oficial da União, 18 de março de 2005. Avaiable in: http://www. mma.gov.br/port/conama/res/res05/res35705.pdf. Access on May 7, 2015.

CAI Y, JIANG G, LIU J AND ZHOU Q. 2003. Multiwalled Carbon Nanotubes as a Solid-Phase Extraction Adsorbent for the Determination of Bisphenol A, 4-n-Nonylphenol, and 4-tert-Octylphenol (MWNTs) for solid-phase extraction of bisphenol A, 4- $\mathrm{n}$ - MWNTs were superior to C 18 for the extraction. Anal Chem 75: 2517-2521.

CAO XK, QIAN QZ, TONG JWL AND WANG Q. 2013. Aquatic Products Determination of Nonylphenol and Octylphenol. Appl Mech Mater 340: 388-391.

CIOFI L, ANCILLOTTI C, CHIUMINATTO U, FIBBI D, CHECCHINI L, ORLANDINI S AND DEL BUBBA M. 2014. Liquid chromatographic-tandem mass spectrometric method for the simultaneous determination of alkylphenols polyethoxylates, alkylphenoxy carboxylates and alkylphenols in wastewater and surface-water. J Chromatogr A 1362: 75-88.

COLBORN T, VOM SAAL FS AND SOTO AM. 1994. Developmental effects of endocrine disrupting chemicals in wildlife and humans. Environ Health Perspect 101: 378-383.

CRUCERU I, IANCU V, PETRE J, BADEA IA AND VLADESCU L. 2012. HPLC-FLD determination of 4-nonylphenol and 4-tert-octylphenol in surface water samples. Environ Monit Assess 184: 2783-2795.

DE SOUSA LEITE G, DE CÁSSIA FRANCO AFONSO RJ AND DE AQUINO SF. 2010. Caracterização de contaminantes presentes em sistemas de tratamento de esgotos, por cromatografia líquida acoplada à espectrometria de massas tandem em alta resolução. Quím Nova 33: 734-738.

DÍAZ A, VENTURA F AND GALCERAN MT. 2002. Simultaneous determination of estrogenic short ethoxy chain nonylphenols and their acidic metabolites in water by an in-sample derivatization/solid-phase microextraction method. Anal Chem 74: 3869-3876.

EL-SHAHAWI MS, HAMZA A, BASHAMMAKH AS AND AL-SAGGAF WT. 2010. An overview on the accumulation, distribution, transformations, toxicity and analytical methods for the monitoring of persistent organic pollutants. Talanta 80: 1587-1597.

FABREGAT-CABELLO N, CASTILLO A, SANCHO JV, GONZÁLEZ FV AND ROIG-NAVARRO AF. 2013. Fast methodology for the reliable determination of nonylphenol in water samples by minimal labeling isotope dilution mass spectrometry. J Chromatogr A 1301: 19-26.

FERNANDES PREVIDELLO BA, DE CARVALHO FR, TESSARO AL, DE SOUZA VR AND HIOKA N. 2006 $\mathrm{O}$ pKa de indicadores ácido-base e os efeitos de sistemas coloidais. Quím Nova 29: 600-606.

FIEDLER S, FOERSTER M, GLASER B AND ZECH W. 2007. Alkylphenols in sediments of the Atlantic Rainforest south-west of São Paulo, Brazil. Chemosphere 66: 212-218.

FRAGA WG. 2012. Identificação e determinação dos principais ingredientes ativos MS agrotóxicos ilegais apreendidos pela Polícia Federal do Brasil. Brasília, 63 p.

FYTIANOSKI,PEGIADOUS, RAIKOSN,ELEFTHERIADIS I AND TSOUKALI H. 1997. Determination of non-ionic surfactants (polyethoxylated-nonylphenols ) by hplc in waste waters. Chemosphere 35: 1423-1429.

GATIDOU G, THOMAIDIS NS, STASINAKIS AS AND LEKKAS TD. 2007. Simultaneous determination of the endocrine disrupting compounds nonylphenol, nonylphenol ethoxylates, triclosan and bisphenol $\mathrm{A}$ in wastewater and sewage sludge by gas chromatographymass spectrometry. J Chromatogr A 1138: 32-41.

GHISELLI G AND JARDIM WF. 2007. Interferentes endócrinos no ambiente. Quím Nova 30: 695-706.

GODOI AFL, FAVORETO R AND SANTIAGO-SILVA M. 2003. Contaminação ambiental por compostos organoestânicos. Quim Nova 26: 708-716.

HERNÁNDEZ F, PORTOLÉS T, PITARCH E AND LÓPEZ FJ. 2007. Target and nontarget screening of organic micropollutants in water by solid-phase microextraction combined with gas chromatography/high-resolution timeof-flight mass spectrometry. Anal Chem 79: 9494-9504.

HUERTA B, JAKIMSKA A, LLORCA M, RUHÍ A, MARGOUTIDIS G, ACUÑA V AND SABATER S. 2015. Development of an extraction and purification method for the determination of multi-class pharmaceuticals and 
endocrine disruptors in freshwater invertebrates. Talanta 132: 373-381.

JEANNOT R, SABIK H, SAUVARD E, DAGNAC T AND DOHRENDORF K. 2002. Determination of endocrinedisrupting compounds in environmental samples using gas and liquid chromatography with mass spectrometry. J Chromatogr A 974: 143-159.

KUCH HM AND BALLSCHMITER K. 2001. Determination of Endocrine-Disrupting Phenolic Compounds and Estrogens in Surface and Drinking Water by HRGC (NCI) - MS in the Picogram per Liter Range. Environ Sci Techn 35: 3201-3206.

LARA-MARTÍN PA, GONZÁLEZ-MAZO E AND BROWNAWELL BJ. 2012. Environmental analysis of alcohol ethoxylates and nonylphenol ethoxylate metabolites by ultra-performance liquid chromatography-tandem mass spectrometry. Anal Bioanal Chem 402: 2359-2368.

LIU R, ZHOU JL AND WILDING A. 2004. Simultaneous determination of endocrine disrupting phenolic compounds and steroids in water by solid-phase extraction-gas chromatography-mass spectrometry. J Chromatogr A 1022: 179-189.

LOU L, CHENG G, YANG Q, XU X, HU B AND CHEN Y. 2012. Development of a novel solid-phase extraction element for the detection of nonylphenol in the surface water of Hangzhou. J Environ Monit 14: 517-523.

MARCOMINI A AND GIGER W. 1987. Simultaneous determination of linear alkylbenzenesulfonates, alkylphenol polyethoxylates, and nonylphenol by high-performance liquid chromatography. Anal Chem 59: 1709-1715.

MARTINEZ M AND PEÑUELA GA. 2013. Analysis of triclosan and 4n-nonylphenol in Colombian reservoir water by gas chromatography-mass spectrometry. Water Environ J 27: 387-395.

MELLO-DA-SILVA CA AND FRUCHTENGARTEN L. 2005. Riscos químicos ambientais à saúde da criança. Jornal de Pediatria 81: S205-S211.

MEYER A, SARCINELLI PN AND MOREIRA JC. 1999. Estarão alguns grupos populacionais brasileiros sujeitos à ação de disruptores endócrinos? Caderno Saúde Pública 15: 845-850.

MNIF W, HASSINE AIH, BOUAZIZ A, BARTEGI A, THOMAS O AND ROIG B. 2011. Effect of endocrine disruptor pesticides: A review. Int J Environ Res Public Health 8: 2265-2303.

MONTAGNER CC AND JARDIM WF. 2011. Spatial and Seasonal Variations of Pharmaceuticals and Endocrine Disruptors in the Atibaia River, São Paulo State (Brazil). J Braz Chem Soc 22: 1452-1462.

OKETOLA AA AND FAGBEMIGUN TK. 2013. Determination of Nonylphenol, Octylphenol and Bisphenol-A in Water and Sediments of Two Major Rivers in Lagos, Nigeria. J Environ Prot 4: 38-45.
ÖMEROĞLU S, MURDOCH FK AND SANIN FD. 2015. Investigation of nonylphenol and nonylphenol ethoxylates in sewage sludge samples from a metropolitan wastewater treatment plant in Turkey. Talanta 131: 650-655.

PETRIE B, MCADAM EJ, WHELAN MJ, LESTER JN AND CARTMELL E. 2013. The determination of nonylphenol and its precursors in a trickling filter wastewater treatment process. Anal Bioanal Chem 405: 3243-3253.

PETROVIC M, BARCELÓ D, DIAZ A AND VENTURA F. 2003. Low nanogram per liter determination of halogenated nonylphenols, nonylphenol carboxylates, and their nonhalogenated precursors in water and sludge by liquid chromatography electrospray tandem mass spectrometry. J Am Soc Mass Spectrom 14: 516-527.

PLANAS C, GUADAYOL JM, DROGUET M, ESCALAS A, RIVERA J AND CAIXACH J. 2002. Degradation of polyethoxylated nonylphenols in a sewage treatment plant. Quantitative analysis by isotopic dilution-HRGC/MS. Water Res 36: 982-988.

REBOUÇAS AC. 2001. Água e Desenvolvimento Rural. Estud Av 15: 327-344.

RENNER R. 1997. European bans on surfactant trigger transatlantic debate. Environ Sci Techn 31: 316A-320A.

RIBEIRO ML, LOURENCETTI C, PEREIRA SY AND DE MARCHI MRR. 2007. Contaminação de águas subterrâneas por pesticidas: Avaliação preliminar. Quím Nova 30: 688-694.

SOARES A, GUIEYSSE B, JEFFERSON B, CARTMELL E AND LESTER JN. 2008. Nonylphenol in the environment: A critical review on occurrence, fate, toxicity and treatment in wastewaters. Environ Int 34: 1033-1049

SODRÉ FF, LOCATELLI MAF AND JARDIM WF. $2010 \mathrm{~b}$. Occurrence of emerging contaminants in Brazilian drinking waters: A sewage-to-tap issue. Water Air Soil Poll 206: 57-67.

SODRÉ FF, PESCARA IC, MONTAGNER CC AND JARDIM WF. 2010a. Assessing selected estrogens and xenoestrogens in Brazilian surface waters by liquid chromatography-tandem mass spectrometry. Microchem J 96: 92-98.

SOLÉ M, DE ALDA MJL, CASTILLO M, PORTE C, LADEGAARD-PEDERSEN K AND BARCELÓ D. 2000. Estrogenicity determination in sewage treatment plants and surface waters from the catalonian area (NE Spain). Environ Sci Techn 34: 5076-5083.

SOUZA RR. 2011. De: Desenvolvimento E Validação De Metodologia Endócrinos Resultantes De Atividades Antrópicas Nas Águas Da Região Do Rio Paraíba Do Sul, SP, 186 p.

SUN A, XU Q AND YU X. 2013. Determination of bisphenol $A$ and 4-nonylphenol in water using ionic liquid dispersive liquid phase microextraction. Pol J Environ Stud 22: 899-907.

SU XF, ZHAO XN, XIE GH AND ZHOU QX. 2012. Fluorometric determination of nonylphenol in water samples 
enriched with zirconium doped titanium dioxide nanotubes solid phase extraction. Chinese ChemLett 23: 969-972.

TERZOPOULOU E, VOUTSA D AND KAKLAMANOS

G. 2014. A multi-residue method for determination of 70 organic micropollutants in surface waters by solid-phase extraction followed by gas chromatography coupled to tandem mass spectrometry. Environ Sci Pollut Res Int 22: 1095-1112.

TUCCI CEM. 2008. Águas Urbanas. Estud Av 22: 97-112.

TUNDISI JG. 2008. Recursos hídricos no futuro: problemas e soluções. Estud Av 22: 7-16.

USEPA. 1998. Research Plan for Endocrine Disruptors. United States Environ. Prot. Agency. Avaiable in: http://www.epa. gov/endocrine-disruption. Access on May 7, 2015.

USEPA. 2004. Safe Drinking Water Act (SDWA). United States Environ. Prot. Agency. Avaiable in: http://www.epa. gov/dwstandardsregulations. Access on May 7, 2015.
USEPA. 2005. Aquatic Life Ambient Water Quality Criteria Nonylphenol - Final. United States Environ. Prot. Agency, Office Water. 2005, EPA-822-R-05-005.

USEPA. 2015. National Primary Drinking Water Regulations. United States Environ. Prot. Agency. Avaiable in: http:// water.epa.gov/drink/contaminants/index.cfm. Access on May 7, 2015.

VIANNA AM. 2015. Poluição ambiental, um problema de urbanização e crescimento desordenado das cidades. Revista Sustinere 3: 22-42.

ZGOŁA-GRZEŚKOWIAK A, GRZEŚKOWIAK T, RYDLICHOWSKI R AND ŁUKASZEWSKI Z. 2009. Determination of nonylphenol and short-chained nonylphenol ethoxylates in drain water from an agricultural area. Chemosphere 75: 513-518. 